\title{
Blood group distribution and its relationship with bleeding time and clotting time
}

\author{
Manjeet Kaur ${ }^{1}$, Arvinder Singh ${ }^{2}$, Roopam Bassi ${ }^{1}$, Deepinder Kaur ${ }^{1}$ \\ ${ }^{1}$ Department of Physiology, Sri Guru Ram Das Institute of Medical Sciences \& Research, Amritsar, Punjab, India. \\ ${ }^{2}$ Department of Radiodiagnosis, Government Medical College, Amritsar, Punjab, India. \\ Correspondence to: Manjeet Kaur, E-mail: manjeetdr@rediffmail.com \\ Received September 26, 2014. Accepted March 9, 2015
}

\section{Abstract}

Background: Blood group plays a vital role in the field of transfusion medicine. The relationship between bleeding time, clotting time, and blood group is important in certain clinical conditions such as epistaxis, surgery, and thrombosis. Researchers have shown that epistaxis is more often encountered in patients having blood group 0 probably due to lower expression of von Willebrand factor, and elevated levels are a risk factor for thrombosis. Thus, earlier studies found prolonged bleeding and clotting time in individuals with 0 blood group. Aims and Objectives: The objective of the study was to assess the relationship between bleeding time and clotting time among various blood groups and to identify any gender difference among the same. Materials and Methods: Our study included 150 MBBS students in the age group of 17-20 years. The blood grouping was carried out with the standard antisera, and bleeding time and clotting time were estimated by Duke method and capillary tube method respectively. Finally, bleeding time and clotting time of different blood groups were compared and statistical analysis was carried out. Results: Blood group B (40.7\%) was the most common blood group in both genders followed by 0 (27.3\%), A (20.7\%), and AB (11.3\%). Bleeding time was found to be prolonged $>4$ min in maximum number of group 0 (22\%) followed by group B (18\%), group AB (5.9\%), and group A $(3.2 \%)$ but the difference was statistically insignificant $(p=0.509)$. Similarly clotting time was $>6$ min in group B $(14.8 \%)$ followed by group $O(14.6 \%)$, group $\mathrm{AB}(11.76 \%)$, and group $\mathrm{A}(9.7 \%)$ but the difference was statistically insignificant $(p=0.885)$. Gender-wise bleeding time was more prolonged in females $(15.7 \%)$ than males $(13.1 \%)$ but the difference was statistically insignificant $(p=0.236)$, similarly clotting time too was prolonged more in females $(16.9 \%)$ than males $(9.8 \%)$ but again the difference was statistically insignificant $(p=0.662)$. Conclusions: In our study, blood group $\mathrm{B}$ predominated followed by $\mathrm{O}, \mathrm{A}$, and $\mathrm{AB}$. Bleeding time was prolonged $>4$ min in blood group 0 followed by $\mathrm{B}$, $\mathrm{AB}$, and $\mathrm{A}$ whereas clotting time was prolonged $>6 \mathrm{~min}$ in blood group $\mathrm{B}$ followed by $\mathrm{O}, \mathrm{AB}$, and $\mathrm{A}$. Gender-wise bleeding and clotting time were higher in females than males.

KEY WORDS: Blood Group; Bleeding Time; Clotting Time; vWf (von Willebrand factor)

\begin{tabular}{|l|l|}
\hline \multicolumn{2}{|c|}{ Access this article online } \\
\hline Website: http://www.njppp.com & Quick Response Code: \\
\hline \multirow{2}{*}{ Do.5455/nippp.2015.5.2609201433 } & \\
\hline
\end{tabular}

\section{INTRODUCTION}

Blood group plays a vital role in the field of transfusion medicine and is genetically determined. ABO blood grouping : is based on antigenic property of red blood cells. Type A individuals have the antigen $\mathrm{A}$, type $\mathrm{B}$ have antigen $\mathrm{B}$, and type $\mathrm{AB}$ have both; type $\mathrm{O}$ have neither of these antigens. These A and B antigens are complex oligosaccharides present :

National Journal of Physiology, Pharmacy and Pharmacology Online 2015. (c) 2015 Manjeet Kaur. This is an Open Access article distributed under the terms of the Creative Commons Attribution 4.0 International License (http://creativecommons.org/licenses/by/4.0/), allowing third parties to copy and redistribute the material in any medium or format and to remix, transform, and build upon the material for any purpose, even commercially, provided the original work is properly cited and states its license. 
on the surface of red blood cells that differ in their terminal sugar. $^{[1]}$ The gene coding for these antigens is located on chromosomes 9 and 19. ${ }^{[2]}$ Recent research data show that ABO blood groups are associated with various diseases such as duodenal ulcer, gastric cancer, diabetes mellitus, urinary tract infection, and venous thrombosis. ${ }^{[3,4]}$ Some authors have found that epistaxis is commonly seen in people with 0 blood group when compared with other ABO blood groups, and they also observed that there is a lower expression of von Willebrand factor (vWf) in them. ${ }^{[5]}$

vWf is a blood glycoprotein involved in hemostasis, synthesized by endothelial cells and megakaryocytes. It helps in platelet adhesion and platelet aggregation. It also acts as a special carrier protein for the clotting factor VIII (anti-hemophilic factor A). Thus, vWf plays an important role in formation of temporary hemostatic plug and its conversion into definite clot by activation of clotting mechanism. The gene codes for vWf are located on chromosome 12p12. Some research papers have proved that other genes like gene locus of $\mathrm{ABO}$ blood group on the chromosome $9 \mathrm{q} 34$ exert a major influence on the $v W f$ gene. ${ }^{[6]}$ Therefore, the $\mathrm{ABO}$ blood group system influences the bleeding time (BT) and clotting time (CT). BT is the time interval between the skin puncture and spontaneous unassisted stoppage of bleeding. CT is the time interval between the puncture between the puncture of blood vessels and formation of fibrin threads. ${ }^{[7]}$ Thus, relationship between BT, CT, and blood groups is important in certain clinical conditions such as epistaxis, cardiac surgery, or thrombosis.

According to Mourant ${ }^{[8]}$. and Qureshi and Bhatti, ${ }^{[9]}$ there is a clear association between ABO blood group status and vWf. Deficiency of vWf leads to hemorrhagic disorders, whereas elevated levels are a risk factor for thrombosis. ${ }^{[10-12]}$ As per the study conducted by Gill et al., ${ }^{[13]}$ group 0 individuals had lowest plasma vWF levels and non-groups $\mathrm{O}(\mathrm{A}, \mathrm{B}$, and $\mathrm{AB}$ ) had elevated levels of plasma vWF. They state that there is increased thrombotic risk among the non- 0 group individuals. This refers to increased BT and CT among 0 group compared to the non- 0 group individuals. At the same time Daniel et al. ${ }^{[11]}$ in their study, could not find any association between $\mathrm{ABO}$ group and vWf. The objective of this study was to assess the relationship between BT and CT among various blood groups, and also to identify any gender difference among the same.

\section{Aims and Objectives}

1. To determine the blood group of the subjects in this study.

2. To determine the BT and CT of the study subjects.

3. To assess the relationship between BT and CT among various blood groups and also to identify any gender difference among the same.

\section{Materials And Methods}

This cross-sectional study was conducted in the Department of Physiology, Sri Guru Ram Das Institute of Medical Sciences \&
Research, Amritsar. After obtaining consent, 150 MBBS students in the age group of 17-20 years were selected. The study was approved by institutional ethical committee. The exclusion criteria for selection of the students were any history of bleeding disorders and drug intake (nonsteroidal anti-inflammatory drugs).

\section{Procedures Done}

Blood group was determined during practical time in physiology laboratory by standard antisera. Blood samples were collected by finger prick with sterile lancet after cleaning the puncture site with spirit. The sample blood was mixed with anti-A, anti-B, and anti-D serum. Blood groups were determined on the basis of presence or absence of agglutination. Agglutination was confirmed by observing under low-power objective of a compound microscope. ${ }^{[14]}$

BT was determined by Duke's filter paper method. A deep skin puncture was made and the length of time required for bleeding to stop was recorded by blotting the drop of blood coming out of the incision every $30 \mathrm{~s}$ using blotting paper. BT was calculated by multiplying the number of drops on the filter paper and $30 \mathrm{~s}$. The normal BT by Duke's filter paper method is usually in the range of 1-5 $\mathrm{min} .^{[14]}$

CT was determined by capillary tube method. A standard incision was made in the skin and the blood was taken into a capillary glass tube. The length of time taken for the blood to clot was calculated by breaking the capillary tube after $2 \mathrm{~min}, 1-2 \mathrm{~cm}$ from one end every $30 \mathrm{~s}$ till appearance of fibrin thread. The normal CT estimated by this method falls in the range of 5-11 $\mathrm{min}^{\left[{ }^{[1]}\right]}$

\section{Statistical Analysis}

The available data were expressed in frequency table and crosstable to find out the sex ratio and to compare different $\mathrm{ABO}$ blood groups. Statistical analysis was carried out using SPSS, version 16 (SPSS Inc., Chicago, IL). The $\chi^{2}$ and one-way analysis of variance (ANOVA) tests were applied to examine association between blood groups and BT, CT; $p$-value of $<0.05$ was considered to be statistically significant.

\section{Table 1: Showing gender percentage among students}

\begin{tabular}{lcc}
\hline Sex & Frequency & Percent \\
\hline Male & 61 & 40.7 \\
Female & 89 & 59.3 \\
Total & 150 & 100 \\
\hline
\end{tabular}

Table 2: Showing distribution and frequency of blood group among students

\begin{tabular}{lcc} 
Blood group & Frequency & Percent \\
\hline A & 31 & 20.7 \\
B & 61 & 40.7 \\
AB & 17 & 11.3 \\
O & 41 & 27.3 \\
Total & 150 & 100 \\
\hline
\end{tabular}




\begin{tabular}{|c|c|c|c|c|c|}
\hline \multirow{3}{*}{$\begin{array}{l}\text { Blood } \\
\text { group }\end{array}$} & \multicolumn{4}{|c|}{ Clotting time } & \multirow{3}{*}{$\begin{array}{l}\text { Significance } \\
\text { (ANOVA) }\end{array}$} \\
\hline & \multicolumn{2}{|c|}{$<6 \min$} & \multicolumn{2}{|c|}{$>6 \min$} & \\
\hline & No. & $\%$ & No & $\%$ & \\
\hline A & 28 & 90.30 & 3 & 9.70 & $F=0.216$ \\
\hline B & 52 & 85.20 & 9 & 14.80 & $p=0.885$ \\
\hline $\mathrm{AB}$ & 15 & 88.23 & 2 & 11.76 & \\
\hline 0 & 35 & 85.40 & 6 & 14.60 & \\
\hline Total & 130 & 86.66 & 20 & 13.33 & \\
\hline
\end{tabular}

Table 4: Distribution of bleeding time on various blood groups with one-way ANOVA analysis

\begin{tabular}{|c|c|c|c|c|c|}
\hline \multirow{3}{*}{$\begin{array}{l}\text { Blood } \\
\text { group }\end{array}$} & \multicolumn{4}{|c|}{ Bleeding time } & \multirow{3}{*}{$\begin{array}{c}\text { Significance } \\
\text { (ANOVA) }\end{array}$} \\
\hline & \multicolumn{2}{|c|}{$>4 \min$} & \multicolumn{2}{|c|}{$<4$ min } & \\
\hline & No & $\%$ & No & $\%$ & \\
\hline A & 30 & 96.80 & 1 & 3.20 & $F=0.776$ \\
\hline B & 50 & 82.00 & 11 & 18.00 & $p=0.509$ \\
\hline $\mathrm{AB}$ & 16 & 94.10 & 1 & 5.90 & \\
\hline 0 & 32 & 78.00 & 9 & 22.00 & \\
\hline Total & 128 & 85.30 & 22 & 14.70 & \\
\hline
\end{tabular}

\begin{tabular}{|c|c|c|c|c|c|}
\hline \multirow[t]{3}{*}{ Sex } & \multicolumn{4}{|c|}{ Clotting time } & \multirow{3}{*}{$\begin{array}{c}\text { Significance } \\
\text { (ANOVA) }\end{array}$} \\
\hline & \multicolumn{2}{|c|}{$>6 \min$} & \multicolumn{2}{|c|}{$<6 \min$} & \\
\hline & No & $\%$ & No & $\%$ & \\
\hline Male & 55 & 90.20 & 6 & 9.80 & $F=0.192$ \\
\hline Female & 74 & 83.10 & 15 & 16.90 & $p=0.662$ \\
\hline Total & 129 & 86.00 & 21 & 14.00 & \\
\hline
\end{tabular}

\section{Results}

The available data of 150 students were analyzed. The age group was homogeneous in our study population (17-20 years) as all of them belonged to the first year of MBBS curriculum. Of 150 students, 61 were males and 89 were females (Table 1). Our results stated that blood group B was more predominant, followed by blood groups $\mathrm{O}, \mathrm{A}$, and $\mathrm{AB}$. The percentage distribution of $\mathrm{ABO}$ blood groups was in order of $\mathrm{B}(40.7 \%)>0(27.3 \%)>\mathrm{A}(20.7 \%)>\mathrm{AB}(11.3 \%)$.

Table 2 shows that the blood group B (40.7\%) was more predominant among students followed by blood group $\mathrm{O}(27.3 \%), \mathrm{A}(20.7 \%)$, and $\mathrm{AB}(11.3 \%)$. The distribution of CT and BT according to blood groups is shown in Tables 3 and 4, respectively. Table 3 shows that CT prolonged more than 6 min
Table 6: Gender-wise distribution of bleeding time with one-way ANOVA analysis

\begin{tabular}{|c|c|c|c|c|c|}
\hline \multirow[t]{3}{*}{ Sex } & \multicolumn{4}{|c|}{ Bleeding time } & \multirow{3}{*}{$\begin{array}{c}\text { Significance } \\
\text { (ANOVA) }\end{array}$} \\
\hline & \multicolumn{2}{|c|}{$>4$ min } & \multicolumn{2}{|c|}{$<4$ min } & \\
\hline & No & $\%$ & No & $\%$ & \\
\hline Male & 53 & 86.90 & 8 & 13.10 & $F=1.417$ \\
\hline Female & 75 & 84.30 & 14 & 15.70 & $p=0.236$ \\
\hline Total & 128 & 85.30 & 22 & 14.70 & \\
\hline
\end{tabular}

among blood group B (14.8\%) followed by 0 (14.6\%), AB (11.76\%), and A (9.7\%). One-way ANOVA tests performed on the data did not show any statistically significant difference between the CT of ABO groups ( $p=0.885)$.

Table 4 shows BT more than $4 \mathrm{~min}$ in a greater number among blood group 0 (22\%) followed by blood group B (18\%), $\mathrm{AB}(5.9 \%)$, and $\mathrm{A}(3.2 \%)$. One-way ANOVA tests performed on the data again did not show statistically significant difference between the BT of ABO groups ( $p=0.509$ ).

While considering the role of sex, CT and BT were more prolonged in females than male, as shown in Tables 5 and 6, respectively. Table 5 shows that the CT is more than $6 \mathrm{~min}$ in $16.9 \%$ females as compared to $9.8 \%$ male students, the difference was not statistically significant $(p=0.662)$. Table 6 shows that $15.7 \%$ female students had more than 4 min of BT compared to $13.1 \%$ male students, the difference was again not statistically significant $(p=0.236)$.

\section{Discussion}

In this study conducted on 150 students, the percentage distribution of blood groups showed predominance of blood group B (40.7\%) followed by 0 (27.3\%), A (20.7\%), and AB $(11.3 \%)$. In India, same prevalence of ABO blood group has been reported, which is in line with that reported in our study. ${ }^{[15]}$ The same trend of prevalence of blood groups $\mathrm{B}>\mathrm{O}>\mathrm{A}>\mathrm{AB}$ was observed in various research studies, which is similar to our study. ${ }^{[16-18]}$ Contrary to our study, Asiatic trend of prevalence of blood groups $\mathrm{O}>\mathrm{B}>\mathrm{A}>\mathrm{AB}$ has been reported by many research studies. ${ }^{[19-22]}$

Several studies have been carried out so far to correlate the association between blood groups and the BT and CT. According to the review article written by Franchini et al., ${ }^{[6]}$ when compared to the type 0 group, the non- $O$ group individuals can have an increased risk of thrombosis due to the higher levels of vWf. The authors also stated that the ABO group can affect the vWF catabolism, which means that the plasma vWF levels may depend on blood group of the individual. This concept was accepted by other studies conducted by Jenkins and O'Donnell, ${ }^{[24]}$ who stated that vWf is $25 \%$ more in non-0 group individuals compared to group 0 individuals. This means that the CT and the BT will be elevated among the 0 group individuals compared to the other groups. In our study also we 
found BT was more prolonged in blood group 0 followed by $\mathrm{B}, \mathrm{AB}$ and $\mathrm{A}$, but the difference was not statistically significant ( $p=<0.05$ ). Similar nonsignificant prolonged BT was seen in blood group $O$ in other studies also. ${ }^{[16,19,25]}$ Contrary to our study, $\mathrm{BT}$ was found more prolonged in the blood group $\mathrm{AB}$ compared to other groups, which was statistically significant. ${ }^{[20,21]}$

In our study, CT was raised in blood group B followed by $0, A B$, and $A$, which was not statistically significant $(p=<0.05)$. Similar nonsignificant raised CT was seen in other studies. ${ }^{[16,19]}$ Similar significant findings were seen in studies carried out by Mahapatra and Mishra ${ }^{[20]}$ and Sasekala and Saikumar. ${ }^{[21]}$

Regarding gender-wise distribution of BT and CT, we observed that there was higher BT and CT in females as compared to males, but it was not statistically significant $(p=<0.05) .^{[16]}$ Similar findings of raised BT and CT were seen in females compared to males but was statistically significant in other studies. ${ }^{[17,22,26]}$ There was no such difference in BT, CT gender-wise in study carried out by Mahapatra and Mishra. ${ }^{[20]}$

\section{Conclusions}

Blood group $\mathrm{B}$ is the most common blood group among the students and $\mathrm{AB}$ is the least common blood group. CT was prolonged $>6$ min among blood group $\mathrm{B}$ followed by $\mathrm{O}, \mathrm{AB}$, and $\mathrm{A}$. BT was prolonged $>4 \mathrm{~min}$ in blood group $\mathrm{O}$ followed by $B, A B$, and $A$. Also there was statistically no significant relation between blood groups, BT, and CT. Gender-wise BT and CT were higher in females than males, but the difference was statistically insignificant. The statistically insignificant values may be due to the small sample size. Further research with larger sample size and conduct of multicentric studies are necessary to confirm this finding of different $\mathrm{ABO}$ blood groups with different bleeding tendencies and their association with vWf and factor VIII so that preventive measures could be adopted before the onset of such disorders.

\section{ACKNOWLEDGMEnTs}

The authors are grateful to the Director Principal and members of the ethics committee for giving permission to conduct this study. In addition, the authors are thankful to the Physiology Department and all the medical students for their full cooperation and participation.

\section{References}

1. Ganong WF. Review of Medical Physiology, 22nd edn. New York: McGraw-Hill Education, 2005. pp. 537.

2. Schleef M, Strobel E, Dick A, Frank J, Schramm W, Spannagi M. Relationship between $\mathrm{ABO}$ and Secretor genotype with plasma levels of factor VIII and von Willebrand factor in thrombosis patients and control individuals. Br J Haematol. 2004;128:100-07.
3. Zhang H, Mooney CJ, Reilly MP. ABO blood groups and cardiovascular diseases. Int J Vasc Med. 2012 (2012); article ID 641917:1-11.

4. Wiggins KL, Smith NL, Glaeer NL, Rosendal FR, Heckbert SR, Psaty $\mathrm{BM}$, et al. ABO genotype and risk of thrombotic events and hemorrhagic stroke. J Thromb Haemost. 2008;7:263-9.

5. Reddy VM, Daniel M, Bright E, Broad SR, Moir AA. Is there an association between blood group 0 and epistaxis? J Laryngol Otol. 2008;122(4):366-8.

6. Franchini M, Franco Capra, Giovanni Targher, Martina Montagnana, Giuseppe Lippi. Relationship between ABO blood group and von Willebrand factor levels: from biology to clinical implications. Thromb J. 2007;5:14.

7. Ghai CL. A Textbook of Practical Physiology, 5th edn. New Delhi: JayPee Brothers, 1999. pp 84-101.

8. Mourant AE. Blood Relations: Blood Groups and Anthropology. Oxford: Oxford University Press, 1983. pp 1-146.

9. Qureshi MA, Bhatti R. Frequency of ABO blood groups among the diabetes mellitus type 2 patients. J Coll Physicians Surg Pak. 2003;13:453-5.

10. Ruggeri ZM, Zimmerman TS. The complex multimetric composition of factor VIII/vWF. Blood. 1981;57:1140-3.

11. Ruggeri ZM. Structure of von Willebrand factor and its function in platelet adhesion and thrombus formation. Best Pract Res Clin Haematol. 2001;14:257-9.

12. Gill JC, Endres-Brooks J, Bauer PJ, Marks WJ Jr, Montgomery RR. The effect of ABO blood group on the diagnosis of von Willebrand disease. Blood. 1987;69(6):1691-5.

13. Daniel M, Jaberoo MC, Stead RE, Reddy VM, Moir AA. Is admission for epistaxis more common in Caucasian than in Asian people? Preliminary study. Clin Otolaryngol. 2006;31:386-89.

14. Pal GK, Pal P. Textbook of Practical Physiology, 3rd edn. 2010. 100-101.

15. Talib HV. Handbook of Medical Laboratory Technology, 2nd edn. New Delhi: CSB Publishers, 1991. 205-210.

16. Patil SV, Gaikwad PB, Vaidya SR, Patil US, Kittad SD. To study the blood group distribution and its relationship with bleeding and clotting time in dental students. Asian J Medical Pharmaceutical Sci. 2013;1(1):1-4.

17. Roy B Banerjee, Sathian B, Mondal M, Saha CG. Blood group distribution and its relationship with bleeding time and clotting time: a medical school based observational study among Nepali. Indian and Sri Lankan students. Nepal J Epidemiol. 2011;1(4):135-40.

18. Abhishekh B, Mayadevi S, Meena D, Usha KC. Distribution of ABO and Rhesus-D blood groups in and around Thiruvananthapuram. Kerala Med J. 2011;1:28-9.

19. Thenmozhi S, Neelambikai N, Aruna P. Comparison of bleeding time and clotting time in different $\mathrm{ABO}$ blood groups. National Journal of Physiology. 2013;1(1):19-24.

20. Mahapatra B, Mishra N. Comparison of bleeding time and clotting time in different blood groups. American J Infectious Dis. 2009; 5(2):113-15.

21. Kohli PG, Kaur H, Maini S. Relationship of bleeding time and clotting time with blood groups. Res J Pharm Biol Chem Sci. 2014; $5(2): 1780-3$.

22. Sasekala M, Saikumar P. Relationship between bleeding time and clotting time among gender difference and varying blood groups in UG medical students. IOSR J Dental Medical Sci. 2013;10(6):40-3.

23. Sadler JE. von Willebrand factor. Ann Rev Biochem. 1998;67:395-424.

24. Jenkins PV, O'Donnell JS. ABO blood group determines plasma von Willebrand factor levels: a biologic function after all? Transfusion. 2006;46(10):1836-44. 
25. Adhikari P, Pramanik T, Pokhael R, Khanal S. Relationship between blood group and epitaxis among Nepalese. Nepal Med Coll J. 2008;10(4):264-5.

26. Kumar SS, VK JM, George J, Mukkadan JK. Bleeding time and clotting time in healthy male and female college students of Karukutty village, Kerala. Health Prospect: J Public Health. 2013;12(1):7-9.
How to cite this article: Kaur M, Singh A, Bassi R, Kaur D. Blood group distribution and its relationship with bleeding time and clotting time. Natl J Physiol Pharm Pharmacol 2015;5:253-257.

Source of Support: Nil, Conflict of Interest: None declared. 